Check for updates

Cite this: J. Mater. Chem. A, 2019, 7, 22012
Received 16th July 2019

Accepted 30th August 2019

DOI: 10.1039/c9ta07693j

rsc.li/materials-a

\section{Synthesis and water oxidation electrocatalytic and electrochromic behaviours of mesoporous nickel oxide thin film electrodes $\uparrow$}

\begin{abstract}
Assel Amirzhanova, ${ }^{a}$ Irmak Karakaya, ${ }^{a}$ Can Berk Uzundal, ${ }^{a}$ Gözde Karaoğlu, ${ }^{a}$ Ferdi Karadas, (DD ${ }^{\text {ab }}$ Burak Ülgüt (iD ${ }^{* a}$ and Ömer Dag (DD *ab

Nickel oxide ( $\mathrm{NiO}$ ) thin film with a high surface area is an important material in electrochemical applications. Spin coating of a preformed clear solution of ethanol, nickel nitrate, and surfactants $\left(\mathrm{C}_{12} \mathrm{H}_{25}\left(\mathrm{OCH}_{2} \mathrm{CH}_{2}\right)_{10} \mathrm{OH}, \mathrm{C}_{12} \mathrm{E}_{10}\right.$ and $\left.\mathrm{C}_{16} \mathrm{H}_{33} \mathrm{~N}\left(\mathrm{CH}_{3}\right)_{3} \mathrm{Br}, \mathrm{CTAB}\right)$ over a substrate produces a lyotropic liquid crystalline phase that is calcined into a transparent mesoporous $\mathrm{NiO}(\mathrm{m}-\mathrm{NiO})$ thin film with a uniform film morphology and high porosity and surface area. $\mathrm{m}-\mathrm{NiO}$, coated over FTO glass, can be used as an electrode in an electrochromic device and electrocatalytic water oxidation processes with excellent efficiency (Tafel slope of $62 \mathrm{mV} \mathrm{dec}^{-1}$ and a low overpotential of $0.200 \mathrm{~V}$ at $1 \mathrm{~mA} \mathrm{~cm}{ }^{-2}$ current density). Repetitive cyclic voltammetry and chronopotentiometry measurements convert the $\mathrm{NiO}$ pore walls into a $\mathrm{NiO} / \mathrm{Ni}(\mathrm{OH})_{2}$ core-shell structure. In the water oxidation process, various $\mathrm{Ni}^{2+}$ surface species on the pore-walls are oxidized to $\mathrm{Ni}^{3+}$ and further to $\mathrm{Ni}^{4+}$ electrocatalytic active species. In an electrochromic device, the oxidation of the $\mathrm{Ni}^{2+}$ species to $\mathrm{Ni}^{3+}$ species reversibly contributes to the electrochromic behaviour, but if the electrochromic device is run at more positive potentials (such as those beyond water oxidation potentials), then electrochromic switching takes place between the $\mathrm{Ni}(\mathrm{OH})_{2}$ and $\mathrm{NiOOH}$ surface species.
\end{abstract}

\section{Introduction}

Nickel oxide and nickel hydroxide have been investigated for a long time as electrode materials and used in various applications such as batteries, water oxidation electro-catalysis, sensors, supercapacitors, solar cells, and electrochromism. ${ }^{1-7}$ The active phase on the nickel oxide surface is the oxidation product, nickel oxyhydroxide $(\beta / \gamma-\mathrm{NiOOH})$, that is reduced to nickel hydroxide $\left(\alpha / \beta-\mathrm{Ni}(\mathrm{OH})_{2}\right)$ in a reverse process. Therefore, the active species on the surface are $\beta / \gamma-\mathrm{NiOOH}$ and $\alpha / \beta-$ $\mathrm{Ni}(\mathrm{OH})_{2}$. Since the active layer in the reduced form is $\mathrm{Ni}(\mathrm{OH})_{2}$ in the electrochemical process, both $\alpha$ and $\beta$ phases of $\mathrm{Ni}(\mathrm{OH})_{2}$ have also been synthesized and used as anode electrode materials in electrocatalysis, sensors, solar cells, electrochromic devices etc..$^{1-7}$ It is also known that $\alpha-\mathrm{Ni}(\mathrm{OH})$ is converted to $\beta$ $\mathrm{Ni}(\mathrm{OH})_{2}$ in a basic electrolyte solution during the electrochemical process. ${ }^{4}$ Therefore, the initially formed crystalline

${ }^{a}$ Department of Chemistry, Bilkent University, 06800, Ankara, Turkey. E-mail: dag@ fen.bilkent.edu.tr; ulgut@fen.bilkent.edu.tr

${ }^{b} U N A M-N a t i o n a l$ Nanotechnology Research Center and Institute of Materials Science and Nanotechnology, Bilkent University, 06800, Ankara, Turkey

$\dagger$ Electronic supplementary information (ESI) available: Composition table, synthesis schema, XRD patterns, extra CV profiles under various conditions, XPS, XANES, and UV-vis spectra, and temperature dependent electrochromic data. See DOI: 10.1039/c9ta07693j
NiO becomes NiO-NiOOH and $\mathrm{NiO}-\mathrm{Ni}(\mathrm{OH})_{2}$ with a NiO crystalline core and an amorphous $\mathrm{NiOOH}$ or $\mathrm{Ni}(\mathrm{OH})_{2}$ shell, respectively, during electrochemical redox cycling. ${ }^{4}$

Many synthesis methods have been developed for the fabrication of nickel oxide in the form of films and powders. ${ }^{8-12}$ Common synthesis methods include sol-gel dip coating, electrochemical deposition, and surfactant templating. ${ }^{8-12}$ However, there is still an ongoing need for cost effective and high-quality thin film fabrication methods. Mesoporous powders and thin films of nickel oxide have also been the subject of many investigations. ${ }^{13-22}$ These synthesis methods involve mainly hard templating, using mesoporous silica KIT-6; ${ }^{13}$ soft templating methods have been developed, mainly using metal ( $\mathrm{Si}, \mathrm{Ti}, \mathrm{Zr}, \mathrm{Nb}$ etc.) alkoxides that hydrolyze/polymerize and assemble into mesostructured solids. ${ }^{23-25}$ However, late transition metals are usually found as nitrate, chloride, or sulfate salts. Most of these salts do not undergo hydrolysis/polymerization reactions under acidic and neutral conditions, but they undergo extremely fast hydrolysis/condensation reactions under basic conditions, where the assembly kinetics cannot compete to form mesostructured metal oxides or metal hydroxides. Therefore, mesoporous transition metal oxides have been primarily prepared using hard templating methods. ${ }^{26-28}$ However, it is difficult to retain the film morphology using hard templating approaches; further steps and other reagents are needed to assemble them into an electrode configuration. Here, we employed the molten- 
salt assisted self-assembly (MASA) method $^{29-32}$ to fabricate mesoporous nickel oxide (m-NiO) as a thin film. The MASA process involves a lyotropic liquid crystalline mesophase that is formed by molten salt and two surfactants. ${ }^{29-32}$ The first step of the MASA process is obtaining a clear solution that can be coated over a substrate with a desired thickness as a lyotropic liquid crystalline gel. Calcination of the thin gel film produces highly transparent m-NiO film.

\section{Results and discussion}

Preparation of homogeneous clear green solutions of salt $\left(\left[\mathrm{Ni}\left(\mathrm{OH}_{2}\right)_{6}\right]\left(\mathrm{NO}_{3}\right)_{2}\right)$ and surfactants (cetyltrimethylammonium bromide, CTAB, and 10-lauryl ether, $\mathrm{C}_{12} \mathrm{E}_{10}$ ) in $5 \mathrm{~mL}$ ethanol is the first step in the process. The salt concentration has been varied from 1 to $30 \mathrm{salt} / \mathrm{C}_{12} \mathrm{E}_{10}$ mole ratio in clear solutions by maintaining all other ingredient concentrations constant (except, above a $12 \mathrm{Ni}(\mathrm{II}) / \mathrm{C}_{12} \mathrm{E}_{10}$ mole ratio, $10 \mathrm{~mL}$ ethanol was used in the solution preparation due to low viscosity of the solutions). The clear solutions are indefinitely stable, over months to years, and can be used at any time upon a homogenization process. Coating the homogenized solution over a substrate immediately produces a thin lyotropic liquid crystalline (LLC) film or spreading it in a Petri dish produces a thick LLC gel phase. Both thin gel films and bulk gel phases diffract at small angles $\left(1-5^{\circ}, 2 \theta\right)$, indicating the formation of the LLC phase, see Fig. 1. The diffraction lines, observed in the XRD pattern of the $6 \mathrm{Ni}(\mathrm{II}) / \mathrm{C}_{12} \mathrm{E}_{10}$ sample, at 1.5 (very intense), 3.0 (very weak) and $2.6^{\circ}$ (very weak) are indexed to the (100), (200), and (110) planes, respectively, of the $2 \mathrm{D}$ hexagonal mesophase. The gels are birefringent up to $8 \mathrm{Ni}(\mathrm{II}) / \mathrm{C}_{12} \mathrm{E}_{10}$ mole ratios and display a focal conic fan texture between the crossed polarizers under a polarized optical microscope (POM), characteristic of a 2D-hexagonal mesophase, see the inset in Fig. 1(a). The images of the samples become dark under a POM above a 10 $\mathrm{Ni}(\mathrm{II}) / \mathrm{C}_{12} \mathrm{E}_{10}$ mole ratio, but these samples still diffract at small angles up to a 30 mole ratio, indicating that the mesophase in this composition range is cubic and disordered. However, at a very high salt concentration, the mesophase gradually leaches out some salt as salt crystals. Salt leaching becomes more obvious and the time required to leach out salt becomes shorter with increasing salt concentration in the media.

The mesophases of the fresh films were denoted as Ni(II)-\#, where \# is the $\mathrm{Ni}(\mathrm{II}) / \mathrm{C}_{12} \mathrm{E}_{10}$ mole ratio. Fig. 1 (a) shows small angle XRD patterns of $\mathrm{Ni}(\mathrm{II})-2, \mathrm{Ni}(\mathrm{II})-4, \mathrm{Ni}(\mathrm{II})-6$, and $\mathrm{Ni}(\mathrm{II})-8$. The intense line at around $1.5-2.0^{\circ}, 2 \theta$, corresponds to the (100) plane of the $2 \mathrm{D}$ hexagonal phase. The corresponding unit cell parameter, $a$, is $53.9,61.8,63.9$, and $67.3 \AA$ for the Ni(II)-2, Ni(II)4, Ni(II)-6, and Ni(II)-8 films, respectively. The (100) line gradually shifts to lower angles with increasing salt concentration in the media, where the unit cell expands about $25 \%$, from Ni(II)-2 to $\mathrm{Ni}(\mathrm{II})-8$. This is a reasonable expansion to accommodate the increased amount of molten salt in the hydrophilic domains of the mesophase. Further expansion with increasing molten salt transforms the 2D-hexagonal into a cubic mesophase. However, the cubic phase is not very stable and undergoes phase separation by leaching out the excess salt and transforms into
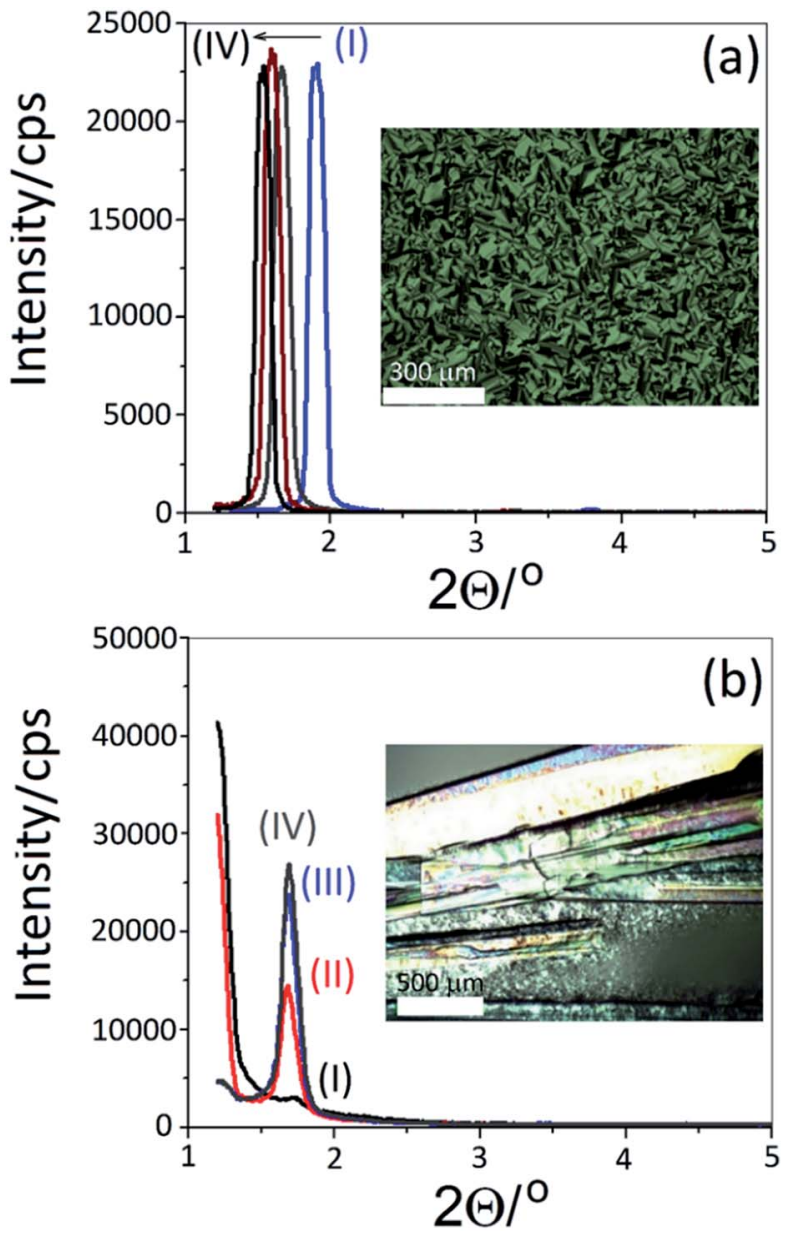

Fig. 1 XRD patterns of (a) (I) 2 and (IV) 8 (middle ones are 4 and 6 in the arrow direction) $\mathrm{Ni}\left({ }_{1}\right) / \mathrm{C}_{12} \mathrm{E}_{10}$ mole ratio mesophases and (b) $15 \mathrm{Ni}(\Perp) /$ $\mathrm{C}_{12} \mathrm{E}_{10}$ mole ratio mesophase over time, (I) immediately after coating, and at (II) 5, (III) 10, and (IV) 20 min. Insets show POM images of the aged samples.

a hexagonal phase. During the transformation, a new line emerges at around $1.7^{\circ}, 2 \theta$, corresponding to the (100) plane of the 2D hexagonal phase, see Fig. 1(b). The POM image upon aging displays salt crystals with a fan texture underneath, correlating the cubic to hexagonal phase change upon leaching of excess salt.

Aging Ni(II)-\# (\# is higher than 6) gels leach some salt crystals, but the salt crystallization becomes visible after several days. With increasing salt content (above 10) in the gel phase, this time decreases from several hours to a few minutes in Ni(II)30. However, even the Ni(II)-30 film can be immediately (within 5 minutes) calcined at $300^{\circ} \mathrm{C}$ to obtain mesoporous nickel oxide (m-NiO).

The calcined films were labelled m-NiO-\#-T, where $\mathrm{m}$ stands for mesoporous, \# is the $\mathrm{Ni}(\mathrm{II}) / \mathrm{C}_{12} \mathrm{E}_{10}$ mole ratio in the precursor solutions, and $T$ is the calcination temperature in Celsius. The gel films were calcined at various temperatures, starting as low as $250{ }^{\circ} \mathrm{C}$. Below a $8 \mathrm{Ni}(\mathrm{II}) / \mathrm{C}_{12} \mathrm{E}_{10}$ mole ratio, the films, calcined at $300{ }^{\circ} \mathrm{C}$, are nanocrystalline $\alpha-\mathrm{Ni}(\mathrm{OH})_{2}$ (see Fig. $2(\mathrm{a})$ ) but above a 8 mole ratio, the films are nanocrystalline $\mathrm{NiO}$ (see Fig. S1(a)†) 

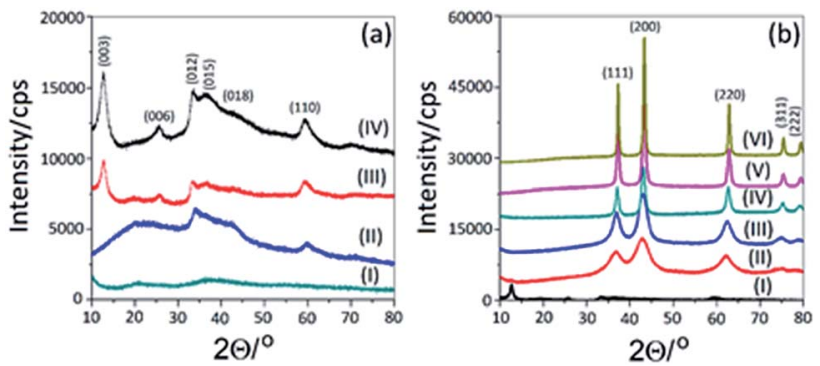

Fig. 2 XRD patterns of the calcined samples of (a) (I) $\mathrm{Ni}($ II) -2 , (II) $\mathrm{Ni}($ II) -4 , (III) $\mathrm{Ni}\left(\right.$ II)-6, and (IV) $\mathrm{Ni}(\mathrm{II})-8$ at $300{ }^{\circ} \mathrm{C}$ and (b) (I) $\mathrm{m}-\mathrm{NiO}-10-250$, (II) $\mathrm{m}$ NiO-10-300, (III) m-NiO-10-350, (IV) m-NiO-10-400, (V) m-NiO-10450, and $(\mathrm{VI}) \mathrm{m}-\mathrm{NiO}-10-500$.

even at $300{ }^{\circ} \mathrm{C}$. Fig. 2 (b) shows the XRD patterns of m-NiO-10-T (where $T$ is $250,300,350,400,450$, and $500{ }^{\circ} \mathrm{C}$ ) samples. The XRD patterns show broad diffraction lines due to $\alpha-\mathrm{Ni}(\mathrm{OH})_{2}$ at $250^{\circ} \mathrm{C}$ and face centered cubic (rock salt) $\mathrm{NiO}$ above $300^{\circ} \mathrm{C}$. The diffraction lines become sharper with increasing calcination temperature, see Fig. 2(b). The particle size, calculated from the XRD patterns using the Scherrer equation, is 3.0, 4.4, 11.4, 15.1, and $27.2 \mathrm{~nm}$, in the m-NiO-10-300, m-NiO-10-350, m-NiO-10400, m-NiO-10-450, and m-NiO-10-500 samples, respectively. All other compositions, at higher $\mathrm{Ni}\left(\mathrm{II}_{\mathrm{II}} / \mathrm{C}_{12} \mathrm{E}_{10}\right.$ mole ratios also produce nanocrystalline mesoporous $\mathrm{NiO}$ upon calcination, see Fig. S1(b). $\dagger$ The nanocrystalline NiO pore walls grow by almost 3 times at around $400^{\circ} \mathrm{C}$ and almost 10 times above $500{ }^{\circ} \mathrm{C}$. Fig. 3 shows two SEM images of m-NiO-10-300, from drop-cast coated samples. Clearly, even the thick samples (larger than $3 \mu \mathrm{m}$ ) display uniform film morphology and porosity. Note also that the thickness of the spin coated film is $300-500 \mathrm{~nm}$ with a similar pore morphology. The film thickness depends on the spin rate and $\mathrm{Ni}(\mathrm{II})$ concentration in the initial solutions. To further investigate the structural details of $\mathrm{m}$-NiO, drop-cast coated samples were used for the XRD and $\mathrm{N}_{2}$ adsorptiondesorption measurements, where large quantities of samples are required.

Fig. 4 shows the $\mathrm{N}_{2}$ adsorption-desorption isotherms and pore size distribution plots of the same samples, used in the XRD analysis. The $\mathrm{N}_{2}$ adsorption-desorption branches are typeIV, characteristic of mesoporous materials. Note also that the surfactant peaks (around 1100 and $2800 \mathrm{~cm}^{-1}$, due to $\mathrm{C}-\mathrm{O}$ and $\mathrm{C}-\mathrm{C}$ and $\mathrm{C}-\mathrm{H}$ stretching regions, respectively) completely disappear in the FTIR spectrum at around $300{ }^{\circ} \mathrm{C}$ (see
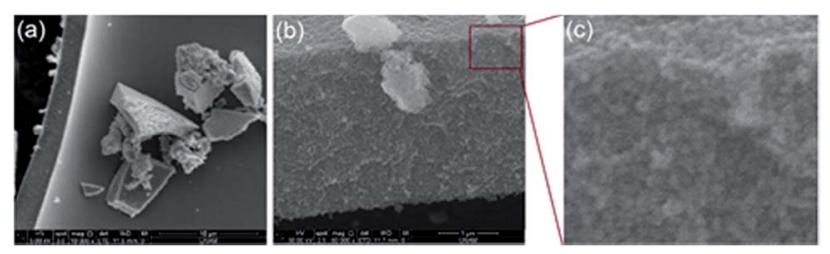

Fig. 3 SEM images of the drop-cast film of $m-\mathrm{NiO}-10-300$ with different magnifications; scale bar is (a) $10 \mu \mathrm{m}$, (b) $1 \mu \mathrm{m}$, and (c) $750 \times$ $750 \mathrm{~nm}$.
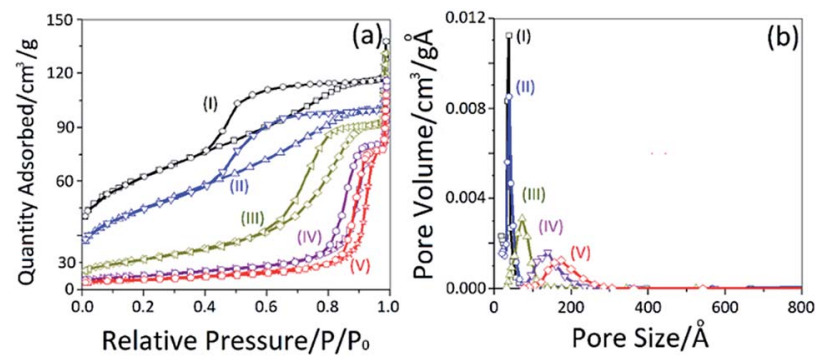

Fig. 4 (a) $\mathrm{N}_{2}(77 \mathrm{~K}$ ) adsorption-desorption isotherms and (b) pore size distribution of (I) $\mathrm{m}-\mathrm{NiO}-10-300$, (II) $\mathrm{m}-\mathrm{NiO}-10-350$, (III) $\mathrm{m}-\mathrm{NiO}-10$ 400, (IV) $\mathrm{m}-\mathrm{NiO}-10-450$, and (V) $\mathrm{m}-\mathrm{NiO}-10-500$.

Fig. S2(a)†), indicating that the surfactant molecules are completely burned off and the pores are fully open above 300 ${ }^{\circ} \mathrm{C}$. Even though surfactant molecules fully burn off above 400 ${ }^{\circ} \mathrm{C}$ for mesoporous materials, it is likely that $\mathrm{m}-\mathrm{NiO}$ catalyzes the oxidation of the surfactant and lowers its decomposition temperature to below $300^{\circ} \mathrm{C}$. The pore size is as small as $3.4 \mathrm{~nm}$ and gradually increases up to $16.9 \mathrm{~nm}$ (obtained by the BarrettJoyner-Halenda (BJH) method using the desorption branches) in the m-NiO-10-300 and m-NiO-10-500 samples, respectively, see Fig. 4(b). The trends of the pore size and the growth of the NiO pore-walls (obtained from XRD results) correlate with each other. The Brunauer-Emmett-Teller (BET) surface area of the samples also follows the same trend and decreases from 223 to $21 \mathrm{~m}^{2} \mathrm{~g}^{-1}$ with increasing calcination temperature from 300 to $500{ }^{\circ} \mathrm{C}$. Other details of the $\mathrm{N}_{2}$ adsorption-desorption data are tabulated in Table 1.

The small angle XRD patterns of the calcined m-NiO-10 (recorded upon calcination at $300{ }^{\circ} \mathrm{C}$ and annealing at 350 and $400{ }^{\circ} \mathrm{C}$, see Fig. S2(b)†) well correlate with the pore size distribution plots. m-NiO-300 diffracts broadly at around $1.4^{\circ}, 2 \theta$, and it gradually shifts to lower angles, $1.2^{\circ}, 2 \theta$, at $350{ }^{\circ} \mathrm{C}$ and $1.0^{\circ}, 2 \theta$, at $400^{\circ} \mathrm{C}$. If we take the pore size $(3.4 \mathrm{~nm})$ and particle size $(3.0 \mathrm{~nm})$ of NiO into account, the broad diffraction lines and the corresponding $d$-spacing $(>6.5 \mathrm{~nm})$ well correlate with the sum of the pore size and particle size which corresponds to the pore to pore distance in disordered mesoporous NiO. Even though the pore size of $\mathrm{m}-\mathrm{NiO}$ at $300{ }^{\circ} \mathrm{C}$ is quite narrow, the diffraction line is very broad because the mesophase becomes

Table $1 \quad \mathrm{~N}_{2}-(77 \quad \mathrm{~K})$ adsorption-desorption data of $\mathrm{m}-\mathrm{NiO}-\mathrm{H}-\mathrm{T}$ samples ( $\mathrm{Ni} / \mathrm{C}_{12} \mathrm{E}_{10}$ mole ratio and $T$ is calcination/annealing temperature in Celsius). A (BET surface area $\left.\left(\mathrm{m}^{2} \mathrm{~g}^{-1}\right)\right), B(\mathrm{BJH}$ pore volume $\left.\left(\mathrm{cm}^{3} \mathrm{~g}^{-1}\right)\right), \mathrm{C}(\mathrm{BJH}$ pore size $(\mathrm{nm}))$

\begin{tabular}{lrlllllr}
\hline m-NiO- & \multicolumn{1}{l}{$A$} & $B$ & $C$ & m-NiO- & \multicolumn{1}{l}{$A$} & \multicolumn{1}{l}{$B$} & \multicolumn{1}{l}{$C$} \\
\hline $2-350$ & 45 & 0.022 & 3.4 & $20-300$ & 225 & 0.145 & 3.5 \\
$4-350$ & 136 & 0.146 & 3.5 & $25-300$ & 257 & 0.155 & 3.5 \\
$6-350$ & 158 & 0.180 & 3.7 & $30-300$ & 183 & 0.091 & 3.5 \\
$8-350$ & 182 & 0.167 & 3.7 & $10-350$ & 164 & 0.176 & 4.1 \\
$10-300$ & 223 & 0.182 & 3.6 & $10-400$ & 61 & 0.204 & 7.2 \\
$12-300$ & 237 & 0.178 & 3.6 & $10-450$ & 28 & 0.180 & 13.4 \\
$15-300$ & 213 & 0.091 & 3.4 & $10-500$ & 21 & 0.167 & 16.9
\end{tabular}


highly disordered or liquid like at temperatures (around $150{ }^{\circ} \mathrm{C}$ ) at which the mesostructured $\mathrm{Ni}(\mathrm{OH})_{2}$ starts forming.

The BET surface area of the samples, calcined at $300{ }^{\circ} \mathrm{C}$, gradually increases from 45 to $237 \mathrm{~m}^{2} \mathrm{~g}^{-1}$ by increasing the salt/ $\mathrm{C}_{12} \mathrm{E}_{10}$ ratio from 2 to 12 . The increase is 3 times by only changing salt/ $\mathrm{C}_{12} \mathrm{E}_{10}$ mole ratio from 2 to 3 , but at higher salt amounts the increase slows and starts decreasing above a 12 $\mathrm{Ni}(\mathrm{II}) / \mathrm{C}_{12} \mathrm{E}_{10}$ mole ratio. The film quality of $\mathrm{m}-\mathrm{NiO}$ \# (where \# is above 12) also becomes low and more fragile. However, the pore size remains constant at around $4 \mathrm{~nm}$ in all compositions, indicating that the pores are formed by micelle surfactant domains in the mesophase. The pores expand by 2 and 4 times by heat treatments at 400 and $500{ }^{\circ} \mathrm{C}$, respectively, see Table 1 . The trends show the role of the mesophase, where the surfactants domains do not alter much with increasing salt content, but the surface area is dependent on the salt content in the hydrophilic domains of the mesophase, where hydrolysis and condensation reactions take place to form m-NiO. We further investigated the electrochemical properties of the samples using m-NiO-10, which is relatively more stable in the LLC phase with a high salt/surfactant ratio.

Fig. 5 shows a set of SEM and TEM images of NiO-10 calcined at 400,450 , and $500{ }^{\circ} \mathrm{C}$. The SEM images show uniform films
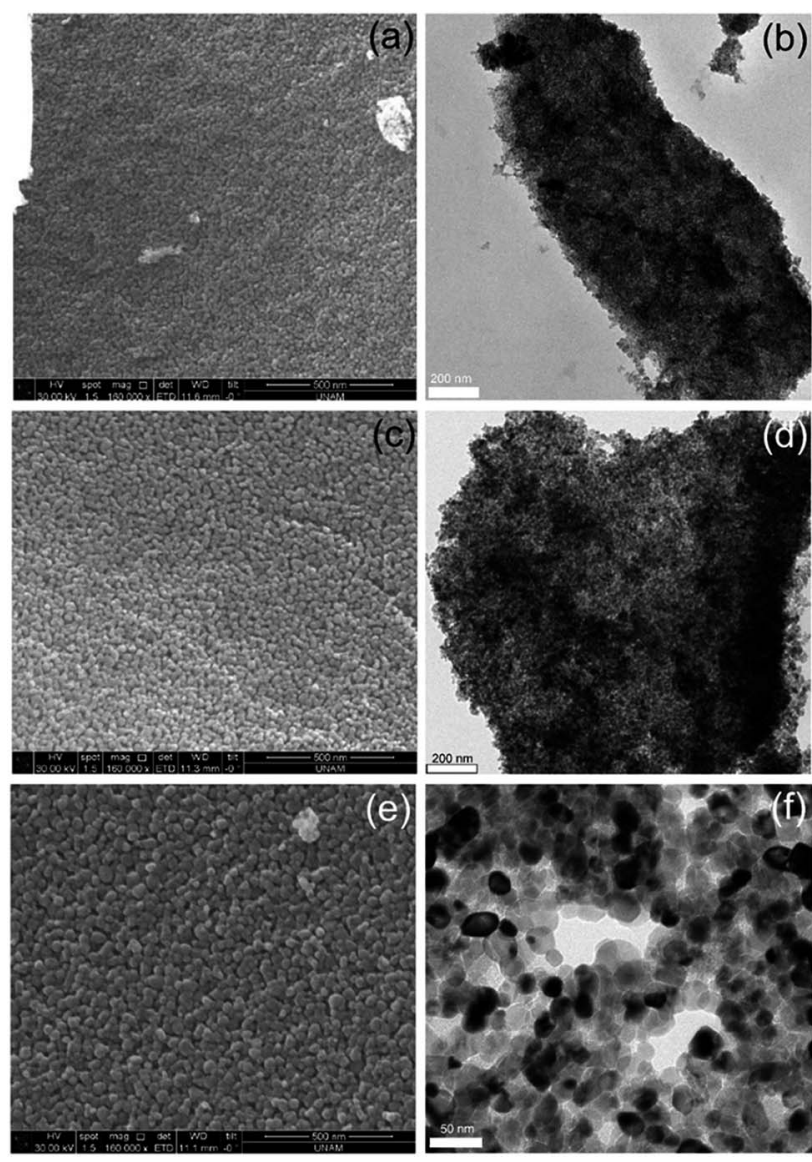

Fig. $51^{\text {st }}$ column shows SEM images of (top to bottom) m-NiO-10$400, \mathrm{~m}-\mathrm{NiO}-10-450$, and $\mathrm{m}-\mathrm{NiO}-10-500$ and the $2^{\text {nd }}$ column shows TEM images of (top to bottom) $\mathrm{m}-\mathrm{NiO}-10-300, \mathrm{~m}-\mathrm{NiO}-10-400$, and $\mathrm{m}-\mathrm{NiO}-10-500$. with a uniform pore system. The TEM images display pore walls made up of nanocrystalline particles, which grow with increasing calcination temperature, consistent with both the $\mathrm{XRD}$ and $\mathrm{N}_{2}$-adsorption-desorption results.

Electrochemical characterization of the films prepared over FTO coated glass was carried out via cyclic voltammetry (CV) in an alkaline solution $(\mathrm{pH}=13.6)$. The CVs display a dominant redox couple at around $0.5 \mathrm{~V}$, relatively smaller peaks at more negative values and catalytic water oxidation processes at more positive potentials. The peak currents of both oxidation and reduction are sensitive to the annealing temperature of the electrodes (see Fig. 6(a)); they decrease with increasing annealing temperature, consistent with the reduction of the electrode surface area. Notice also that there is a gradual shift of the oxidation peak to more positive potentials and increase in the peak current in the $\mathrm{CV}$ profiles upon repeating an oxidation-reduction cycle, see the inset in Fig. 6(a). Clearly, the catalytic activity of the electrode increases over the cycles. Fig. 6(b) shows the CV profile of the electrode in more detail. The redox feature at around $0 \mathrm{~V}$ disappears after 50 cycles and reappears upon calcination, which can be attributed to a chemical change in the nature of the electrode surface. Based on this information and the later discussion, we assign the redox features at around $0.5 \mathrm{~V}$ to the $\mathrm{Ni}(\mathrm{OH})_{2} / \mathrm{NiOOH}$ couple, whereas the features at less positive potentials to $\mathrm{NiO} / \mathrm{NiOOH}$ couples originating from various NiO surfaces, see Scheme 1. Scheme 1 shows the likely surface sites on different crystallographic surfaces of $\mathrm{NiO}$ with a symmetry axis and likely charges around surface $\mathrm{Ni}^{2+}$. These surface charges are the likely origin of different oxidation potentials for different $\mathrm{Ni}^{2+}$ sites. (a)

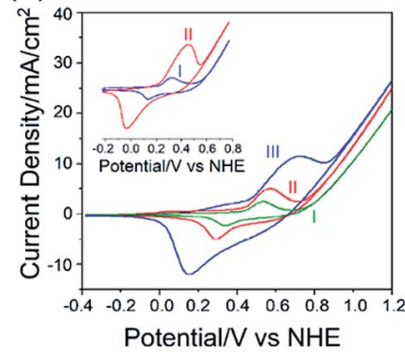

(c)

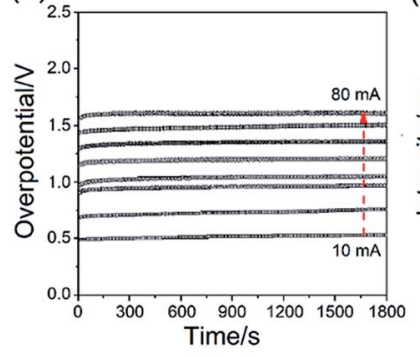

(b)

(d)

Potential/V vs NHE

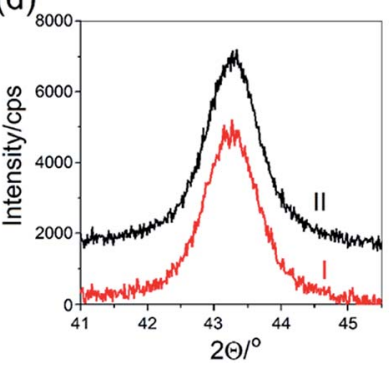

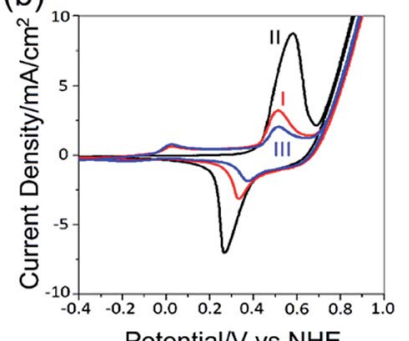

Fig. 6 (a) CVs of $\mathrm{m}-\mathrm{NiO}-10$ electrodes calcined at (I) 500 , (II) 400 , and (III) $300^{\circ} \mathrm{C}$. Inset: (I) before and (II) after chronopotentiometry (18 h). (b) CVs of m-NiO-10-400: (I) $1^{\text {st }}$ and (II) $50^{\text {th }} \mathrm{CV}$ cycles, and (III) $1^{\text {st }} \mathrm{CV}$ cycle after recalcination of (II) at $300^{\circ} \mathrm{C}$. (c) CP from 10 to $80 \mathrm{~mA} \mathrm{~cm}^{-2}$ (bottom to top) of $\mathrm{m}-\mathrm{NiO}-10-300$ and (d) (200) XRD line of $\mathrm{m}-\mathrm{NiO}-$ 10-300 (I) before and (II) after CP (18 h). 


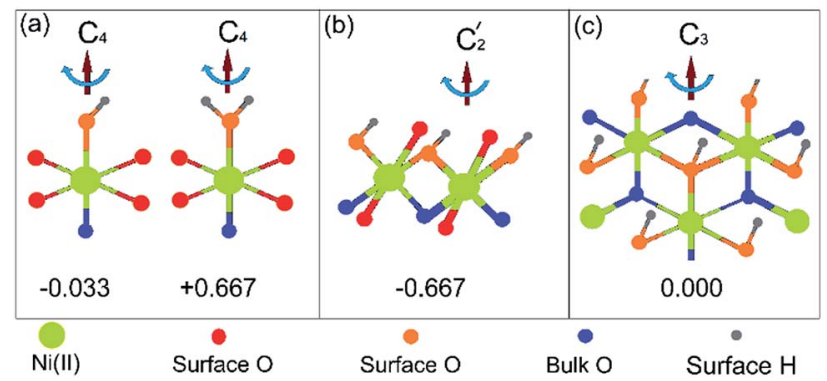

Scheme 1 Likely surface species of various surfaces: (a) (100), (b) (110), and (c) (111) with a calculated charge around Ni(॥).

Therefore, the oxidation peaks from 0 to $0.5 \mathrm{~V}$ could be assigned to $\mathrm{Ni}^{2+}$ to $\mathrm{Ni}^{3+}$ surface sites. We also prepared $\mathrm{Ni}(\mathrm{OH})_{2}$ and recorded its $\mathrm{CV}$ which displays a broad oxidation feature above $0.5 \mathrm{~V}$ due to the $\mathrm{Ni}(\mathrm{OH})_{2} / \mathrm{NiOOH}$ couple and does not change upon cycling (see Fig. S3†), consistent with the above assignment.

A large shift in the oxidation and reduction peak position indicates a chemical change during oxidation and reduction processes. The reduced species in the reverse cycle is no longer $\mathrm{NiO}$ species when the CV cycles are carried out between -0.2 and 1.2 V. This is also observed when we perform a chronopotentiometry (CP) experiment, see Fig. 6(c). The electrode (m-NiO-10-300) displays a current density of $1 \mathrm{~mA} \mathrm{~cm}^{-2}$ at an overpotential of $291 \mathrm{mV}$, which decreases to $259 \mathrm{mV}$ over $1 \mathrm{~h}$ of use, consistent with the observations in CV curves. We performed the same experiments at higher current densities from 10 to $80 \mathrm{~mA} \mathrm{~cm}{ }^{-2}$ with $10 \mathrm{~mA} \mathrm{~cm}{ }^{-2}$ increments to investigate the origin of the change. We found that the overpotential remains almost constant at higher currents with a very small increase at a constant current in the CP curves. Therefore, the likely change in the overpotential at $1 \mathrm{~mA} \mathrm{~cm} \mathrm{~cm}^{-2}$ is completely due to chemical changes at the electrode surface during the oxidation process. Notice also that the overpotential increases linearly as a function of current with a slope of 15 ohms, indicating that the added potential is purely ohmic and originates mainly from the FTO substrate (see Fig. 6(c)). ${ }^{33}$ The overpotentials are around 0.263 and $0.330 \mathrm{~V}$ at 1 and $10 \mathrm{~mA} \mathrm{~cm}{ }^{-2}$, respectively, and $0.406 \mathrm{~V}$ at a higher current density of $80 \mathrm{~mA}$ $\mathrm{cm}^{-2}$, after IR compensation.

The slope of the peak current intensity versus scan rate plot provides information on the surface coverage of active sites. ${ }^{32}$ The surface coverage of the electrode (m-NiO-10), calcined at $350{ }^{\circ} \mathrm{C}$ decreases from 219 to $110 \mathrm{~nm} \mathrm{~cm}^{-2}$ upon annealing at $450{ }^{\circ} \mathrm{C}$. This is also consistent with the reduced surface area by high temperature treatment. Notice that the surface area also decreases from 164 to $28 \mathrm{~m}^{2} \mathrm{~g}^{-1}$ and the crystallite size increases from 4.4 to $15.1 \mathrm{~nm}$ by annealing the electrode from 350 to 450 ${ }^{\circ} \mathrm{C}$, respectively. However, the electrode annealed at $450{ }^{\circ} \mathrm{C}$ displays an overpotential of $0.266 \mathrm{~V}$ that decreases to $0.200 \mathrm{~V}$ at a current density of $1 \mathrm{~mA} \mathrm{~cm}{ }^{-2}$ after a $5 \mathrm{~h}$ chronopotentiometry (CP) experiment, while the one annealed at $350{ }^{\circ} \mathrm{C}$ displays a slightly higher overpotential (from 0.284 to $0.271 \mathrm{~V}$ in $5 \mathrm{~h}$ ). These two electrodes were also used to determine the overpotentials required for higher current densities (from 10 to 60 $\mathrm{mA} \mathrm{cm}{ }^{-2}$ with $10 \mathrm{~mA} \mathrm{~cm}{ }^{-2}$ increments) by CP measurements. The slope, from the overpotential versus current density plot, corresponds to the resistance of the electrodes (consist of FTO and $\mathrm{m}-\mathrm{NiO}$ ), which is 26.6 and $16.5 \Omega$ including the FTO substrate (obtained from impedance measurements), annealed at 350 and $450{ }^{\circ} \mathrm{C}$, respectively. Even though the electrode annealed at $350{ }^{\circ} \mathrm{C}$ exhibits a relatively higher surface area and performs better at low current densities, the electrode annealed at $450{ }^{\circ} \mathrm{C}$ performs much better at elevated current densities as a water oxidation electrocatalyst. The potential loss is purely ohmic in the electrode with a high surface area, due to high electrode resistance. The Tafel slope (62 mV $\mathrm{dec}^{-1}$ ) of the electrode (m-NiO-10-450) is comparable to that of cobalt and nickel-based water oxidation electrocatalysts in the literature. ${ }^{32-37}$ The overpotentials, extracted from the Tafel equation, are 288 and $350 \mathrm{mV}$ at current densities of 1 and $10 \mathrm{~mA} \mathrm{~cm} \mathrm{~cm}^{-2}$, which are quite consistent with the experimental values once the IR drop is subtracted from the experimental data.

The post-catalytic m-NiO-10-400 after the $1 \mathrm{~h}$ electrolysis experiment was further analyzed using the XRD technique. Fig. 6(d) shows two patterns of the same electrode before and after water oxidation. Clearly, the diffraction lines due to cubic NiO did not alter upon oxidation. Even though the peak current increases in the CV upon the use of the electrode for the water oxidation process, there is no change in the full width at half maximum of the line at $43.3^{\circ}, 2 \theta$, corresponding to the (200) plane of NiO. The trend in the CVs upon repeated cycling and XRD patterns clearly show that the top few layers of $\mathrm{NiO}$ are converted to $\mathrm{Ni}(\mathrm{OH})_{2}$, where the transformation proceeds up to a certain extent (notice the gradual increase of the oxidation and reduction peak current in multiple $\mathrm{CV}$ cycles, see Fig. $\mathrm{S} 4 \dagger$ ) without reducing the NiO crystallite size in the pore walls within the XRD detection limits. Scheme 2 summarizes the transformation on the electrode surface during the electrochemical process.

It has been already established that the oxidation product of nickel oxide is $\mathrm{NiOOH}$, which is reduced to $\alpha-\mathrm{Ni}(\mathrm{OH})_{2}$ followed

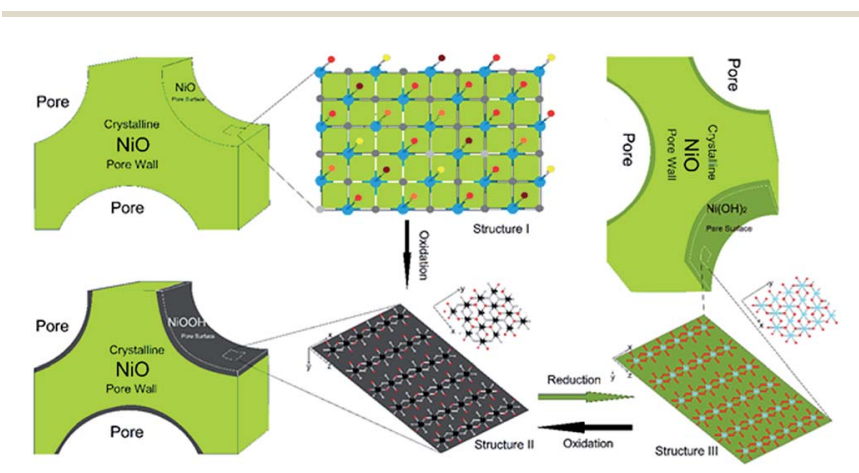

Scheme 2 Schematic representation of mesoporous $\mathrm{NiO}$ before and after oxidation-reduction cycles with surface composition. Structure I: NiO surface and surface species; each color code indicates different species (such as $\mathrm{OH}, \mathrm{H}_{2} \mathrm{O}$, etc.), structure II: $\mathrm{NiOOH}$ surface species, black atoms are $\mathrm{Ni}^{3+}$, red spheres $\mathrm{OH}$ sites and gray $\mathrm{O}$, and structure III: $\mathrm{Ni}(\mathrm{OH})_{2}$ surface species, light blue $\mathrm{Ni}^{2+}$, and red $\mathrm{OH}$ groups. Oxygen is coordinated to $6 \mathrm{Ni}$ in $\mathrm{NiO}$ and $3 \mathrm{Ni}$ in both $\mathrm{NiOOH}$ and $\mathrm{Ni}(\mathrm{OH})_{2}$ (except surface oxygens). 
by transformation to $\beta-\mathrm{Ni}(\mathrm{OH})_{2}$ under basic conditions. ${ }^{38} \mathrm{We}$ also demonstrated the presence of such a transformation by comparing the XRD patterns of a freshly prepared $\alpha-\mathrm{Ni}(\mathrm{OH})_{2}$ phase and the one after aging under basic conditions. Clearly the diffraction lines of $\alpha-\mathrm{Ni}(\mathrm{OH})_{2}$ disappear and those of the $\beta$ $\mathrm{Ni}(\mathrm{OH})_{2}$ phase appear, see Fig. S5. $\dagger$ There is also a debate regarding the activity of both $\alpha-\mathrm{Ni}(\mathrm{OH})_{2}$ and $\beta-\mathrm{Ni}(\mathrm{OH})_{2}$ phases and the oxidation products, $\beta-\mathrm{NiOOH}$ and $\gamma-\mathrm{NiOOH} .{ }^{4}$ It is likely that the surface of $\mathrm{m}-\mathrm{NiO}$ is covered with both $\beta-\mathrm{NiOOH}$ and $\gamma$ $\mathrm{NiOOH}$, which form during the water oxidation process, and $\alpha$ $\mathrm{Ni}(\mathrm{OH})_{2}$ and $\beta-\mathrm{Ni}(\mathrm{OH})_{2}$ during the reverse scan. ${ }^{39,40}$ This may clarify the changes in the CV curves over multiple cycles (see Fig. S4 $\dagger$ ). Since the active layer is a form of $\mathrm{Ni}(\mathrm{OH})_{2}$, which is not observed in the XRD pattern, the absence of any decrease or broadening in the NiO diffraction lines (within detection limits of XRD) indicates that only one or two top layers of the $\mathrm{NiO}$ surface (these layers are likely amorphous with a composition of $\left.\mathrm{NiO}_{1-x}(\mathrm{OH})_{2 x}\right)$ participate in the transformation process that takes place during $\mathrm{CV}$ measurements and the darkening and bleaching process in the electrochromic tests (see later).

To further characterize and investigate the electrochemical characteristics of the electrodes, the CVs of the fresh, used, and used and calcined electrodes were recorded, see Fig. 6(b). The freshly prepared film displays oxidation peaks at 0.027 and $0.515 \mathrm{~V}$ (vs. $\mathrm{Ag} / \mathrm{AgCl})$ due to $\mathrm{NiO}$ and $\mathrm{Ni}(\mathrm{OH})_{2}$ surface species. As discussed above, the reduction of $\mathrm{NiOOH}$ yields $\mathrm{Ni}(\mathrm{OH})_{2}$ rather than NiO; thus, the NiO oxidation peak does not recover during the reduction cycle and further CV cycles. However, if the used electrode is recalcined at $400{ }^{\circ} \mathrm{C}$, surface $\mathrm{NiO}$ is recovered and its oxidation peak reappears with a higher peak current density, indicating reformation/recrystallization of $\mathrm{NiO}$ on the surface, see Fig. 6(b). Note also that the increase in the peak current ratio of $\mathrm{NiO} / \mathrm{Ni}(\mathrm{OH})_{2}$ compared to the fresh sample after recrystallization indicated that this process produces more surface NiO species at the expense of $\mathrm{Ni}(\mathrm{OH})_{2}$, see Fig. 6(b). This transformation may alter the electrode surface morphology. This is only possible if the $\mathrm{Ni}(\mathrm{OH})_{2}$ shell is converted into smaller NiO nanocrystals over the core NiO pore walls with a higher surface area. This may also effectively explain the enhancement of the oxidation peak and activity of the electrode towards water oxidation during use. However, the proof of this proposal needs detailed in situ high resolution TEM imaging.

There is also a debate in the literature regarding the color of $\mathrm{NiO}$; the origin of the black color is assigned to $\mathrm{Ni}^{3+}$ species ${ }^{41}$ or the presence of metallic nickel ${ }^{42}$ in the samples. The color of the as-synthesized films also varies from clear transparent to black transparent upon calcination, but the black samples become clear upon washing using a strong reducing agent, $\mathrm{NaBH}_{4}$ solution. However, after $\mathrm{NaBH}_{4}$ treatment, washing the clear films several times with distilled water reestablishes the darker color back on the films. $\mathrm{NaBH}_{4}$ dipping and washing were monitored using UV-vis spectroscopy, see Fig. S6. $\uparrow$ The black colored sample displays broad absorption in the visible region and the color disappears upon reducing $\mathrm{Ni}^{3+}$ species and partially re-appears upon washing with distilled water and drying, showing re-oxidation of the surface, see Fig. S5.† Both observations (disappearing and appearing of the black color on the films) overrule the presence of metallic nickel in the samples, and our data show that the origin of the black color in the as-synthesized $\mathrm{m}$-NiO films is the $\mathrm{Ni}^{3+}$ surface species, likely in the form of $\beta / \gamma-\mathrm{NiOOH}$. Since the surface area of $\mathrm{m}-\mathrm{NiO}$ is large enough, the $\mathrm{Ni}^{3+}$ species are visible to the naked eye (as a dark color).

The $\mathrm{Ni}^{2+} / \mathrm{Ni}^{3+}$ species were further characterized using XPS spectroscopy. Fig. S7† shows the XPS of m-NiO-10 before and after electrocatalytic use of the films. Clearly, before use, the $\mathrm{Ni}$ 2 p peaks of $\mathrm{NiO}$ dominate the $\mathrm{Ni} 2 \mathrm{p}$ region. The peaks at 854.0 and $856.0 \mathrm{eV}$ are assigned to the ${ }^{2} \mathrm{P}_{3 / 2}$ spin-orbit state of different NiO surface species. The spectrum changes with electrochemical oxidation and new peaks appear at 854.0 and $855.7 \mathrm{eV} .^{43}$ The low energy peak loses its intensity while a new peak at $855.7 \mathrm{eV}$ appears with a higher intensity. It is likely that the new peak is due to $\mathrm{NiOOH}$ and $\mathrm{Ni}(\mathrm{OH})_{2}$ species on the electrode surface. Moreover, the NiO peak does not completely disappear from the spectrum, see Fig. S7. $\dagger$ This is consistent with our proposal that a very thin skin on the surface is converted to $\mathrm{Ni}(\mathrm{OH})_{2}$ during electrochemical cycling. Since XPS is a surface sensitive technique and mostly measures 3-4 nm of the top surface layer of the electrode, the spectrum is dominated by the surface species that are not detected by XRD.

The Ni K-edge XANES data were also collected using m-NiO10 (calcined at 300, 400, and $600{ }^{\circ} \mathrm{C}$ ), $\mathrm{Ni}(\mathrm{OH})_{2}$, and $\mathrm{m}-\mathrm{NiO}-10-$ 400 after $200 \mathrm{CV}$ cycles in $1.0 \mathrm{M} \mathrm{KOH}$ solution, see Fig. $\mathrm{S} 8 \dagger$ for further electronic evidence to support our proposal. Clearly, there is a visible difference between $\mathrm{m}-\mathrm{NiO}-300$ and $\mathrm{m}-\mathrm{NiO}-400$, where the crystallite size is 3.0 and around $10 \mathrm{~nm}$, respectively. The difference can be explained by the size effect. The XANES spectrum of $\mathrm{Ni}(\mathrm{OH})_{2}$ is also shown in Fig. S8† for comparison purpose. Note also that the spectrum of $\mathrm{m}$-NiO does not change upon annealing above $400{ }^{\circ} \mathrm{C}$. Furthermore, XANES is an absorption and bulk technique compared to XPS and provides information on the electronic structure of the entire pore-walls. As shown in the spectra, after $200 \mathrm{CV}$ cycles, the Ni K-edge XANES spectrum displays a little or almost no spectral change and it is consistent with our XRD data, showing that there is a very thin shell of the active layer (likely $\mathrm{Ni}(\mathrm{OH})_{2}$ that is converted from NiO during $\mathrm{CV}$ cycles) over the pore-walls (see Scheme 2), but that the core of the pore-walls remains crystalline $\mathrm{NiO}$ in the m-NiO film during the oxidation process.

To further prove our proposal, the following experiments were conducted. First, we zoomed into the region of the CVs which are negative for the signal that is assigned to the $\mathrm{Ni}(\mathrm{OH})_{2} /$ $\mathrm{NiOOH}$ couple. Avoiding these positive potentials, the CVs of the electrodes (m-NiO-10, calcined at 300,400 , and $500{ }^{\circ} \mathrm{C}$ ) are stable upon cycling and show a multitude of redox couples as shown in Fig. 7(a). The relative ratios of the charge under the oxidation peaks around 0.0 and $0.3 \mathrm{~V}$ vary with the calcination/ annealing temperature, yet for a given sample, stay constant upon cycling, see Fig. 7(b).

These two electrochemical signals were investigated in two separate experiments. First, the $\mathrm{pH}$ dependence of the electrochemical potentials was investigated in buffer solutions by measuring the CVs at various $\mathrm{pH}$ levels, see Fig. S9. $\uparrow$ The $\mathrm{pH}$ dependence of the electrochemical potentials is shown in 

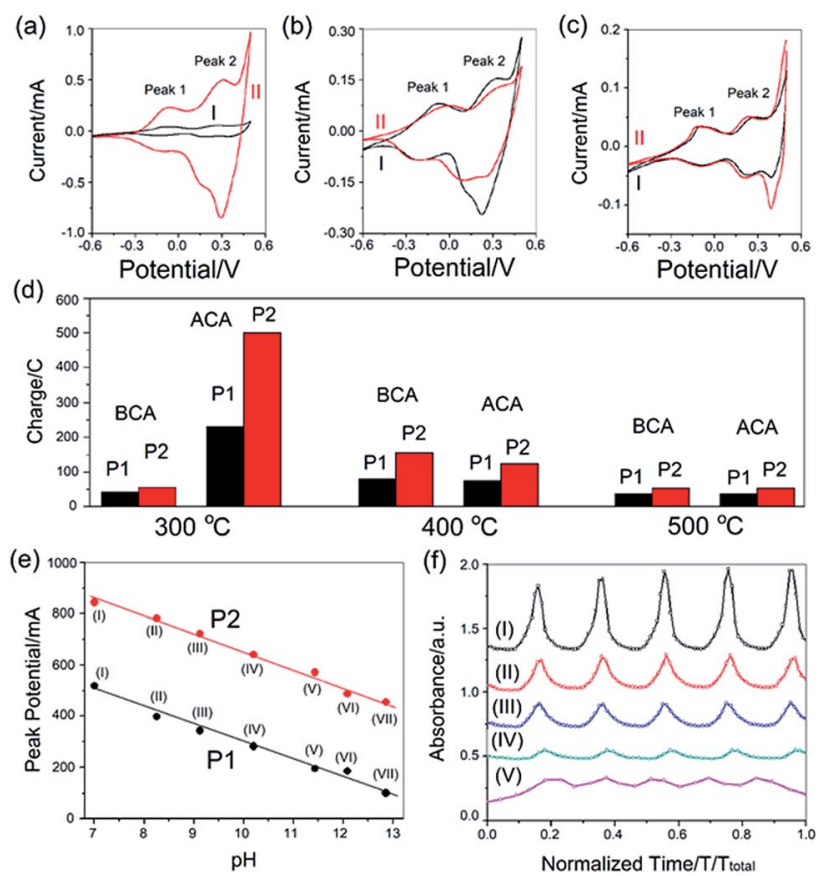

Fig. $7 \mathrm{CV}$ of $\mathrm{m}-\mathrm{NiO}-10$ calcined at (a) $300{ }^{\circ} \mathrm{C}$, (b) $400{ }^{\circ} \mathrm{C}$, and (c) 500 ${ }^{\circ} \mathrm{C}$ ((I) before chronoamperometry-BCA and (II) after chronoamperometry-ACA) and (d) the corresponding charge under each peak ( $\mathrm{P} 1$ is peak 1 and $\mathrm{P} 2$ is peak 2); (e) $\mathrm{pH}$ dependent peak potential in $\mathrm{mV}$ of $\mathrm{m}-\mathrm{NiO}-10-300$ at $\mathrm{P} 1$ and $\mathrm{P} 2$ at $\mathrm{pH}$ values of (I) 7, (II) 8.25 , (III) 9.12, (IV) 10.2, (V) 11.43, (VI) 12.08, and (VII) 12.85 and (f) electrochromic behavior of $\mathrm{m}-\mathrm{NiO}-10-300$, absorbance vs. normalized time plot of voltage intervals of (I) -500 to $500 \mathrm{mV}$, (II) -500 to $400 \mathrm{mV}$, (III) -500 to $345 \mathrm{mV}$, (IV) -500 to $150 \mathrm{mV}$, and (V) 150 to $500 \mathrm{mV}$.

Fig. 7(c). The slopes of both curves are roughly $70 \mathrm{mV} \mathrm{pH}^{-1}$, which is an indication that both processes are close to one electron one proton reactions and they are similar in their $\mathrm{pH}$ dependencies. Furthermore, Fig. 7(d) shows a set of plots collected from electrochromic switching experiments performed at different potential windows. All peaks show a change in the color intensity upon oxidation (dark) or a reduction (clear). This is another indication that the processes observed are connected to transitions between $\mathrm{a} \mathrm{Ni}^{2+}$ and $\mathrm{Ni}^{3+}$ species. The change in the absorbance at $500 \mathrm{~nm}$ is a function of the charge under the corresponding peak and as mentioned before, it is also a function of the annealing temperature. Notice that the highest contrast is obtained from the electrodes annealed at $300{ }^{\circ} \mathrm{C}$ and lowest for the electrodes annealed at $500{ }^{\circ} \mathrm{C}$, see Fig. S10. $\dagger$ The surface area and surface $\mathrm{Ni}^{2+}$ concentration could be the determining factors in the electrochromic behaviors of the electrodes.

The peaks, 1 (around $0 \mathrm{~V}$ ) and 2 (around $0.3 \mathrm{~V}$ ), are reversible if the sweep is carried from -0.5 and $0.5 \mathrm{~V}(v s$. NHE) and become irreversible upon sweeping $\mathrm{CV}$ between -0.5 and $1.2 \mathrm{~V}$ (vs. NHE), indicating that the surface species switches from $\mathrm{Ni}^{2+}$ to $\mathrm{Ni}^{3+}$ unless the potential required for water oxidation is applied. Exceeding 1.0 V in CV cycles and CP experiments produces $\mathrm{Ni}^{4+}$ species on the electrode surface which are the electroactive sites for electrocatalysis of water oxidation. The $\mathrm{Ni}^{4+}$ species transforms into $\mathrm{Ni}(\mathrm{OH})_{2}$ in the reverse process and therefore transforms the $\mathrm{NiO}$ surface into a $\mathrm{Ni}(\mathrm{OH})_{2}$ surface. The only evidence for the formation of $\mathrm{Ni}^{4+}$ is found in the slow scan $\left(1 \mathrm{mV} \mathrm{s}^{-1}\right) \mathrm{CV}$ profile that displays a well resolved peak at around $0.52 \mathrm{~V}$ (vs. NHE), see Fig. S11. $\dagger$ Currently, the chemical composition of the $\mathrm{Ni}^{4+}$ species is unknown. Further characterization of the $\mathrm{Ni}^{4+}$ species may require in situ analysis during CP experiments by using surface sensitive techniques.

\section{Experimental}

\section{Synthesis}

All the ingredients, nickel nitrate hexahydrate $\left(\left[\mathrm{Ni}\left(\mathrm{H}_{2} \mathrm{O}\right)_{6}\right](-\right.$ $\left.\mathrm{NO}_{3}\right)_{2}$ ), cetyltrimethylammonium bromide (CTAB), and 10 lauryl ether $\left(\mathrm{C}_{12} \mathrm{E}_{10}, \mathrm{C}_{12} \mathrm{H}_{25}\left(\mathrm{OCH}_{2} \mathrm{CH}_{2}\right)_{10} \mathrm{OH}\right)$, were purchased from Sigma-Aldrich and used without further purification. The solutions were prepared by keeping the surfactant concentrations constant and varying the salt amount as $1 \mathrm{CTAB}: 1 \mathrm{C}_{12^{-}}$ $\mathrm{E}_{10}: x\left[\mathrm{Ni}\left(\mathrm{OH}_{2}\right)_{6}\right]\left(\mathrm{NO}_{3}\right)_{2}$ ( $x$ was varied from 2 to 30$)$. In a typical synthesis, $291 \mathrm{mg}$ CTAB, $500 \mathrm{mg} \mathrm{C}_{12} \mathrm{E}_{10}, 5 \mathrm{~mL}$ ethanol and the corresponding amount of Ni(II) salt (see Table S1 $\dagger$ ) were used to prepare clear solutions. The amount of ethanol was $5 \mathrm{~mL}$ for up to $12 \mathrm{Ni}(\mathrm{II}) / \mathrm{C}_{12} \mathrm{E}_{10}$ mole ratio and $10 \mathrm{~mL}$ between 15 and 30 $\mathrm{Ni}(\mathrm{II}) / \mathrm{C}_{12} \mathrm{E}_{10}$ mole ratios.

First Ni(II) salt and charged surfactant were added to a vial with $5 \mathrm{~mL}$ ethanol and the mixture was stirred for $15 \mathrm{~min}$ on a magnetic stirrer to obtain a clear solution. Then, the non-ionic surfactant $\left(\mathrm{C}_{12} \mathrm{E}_{10}\right)$ was added to the clear solution and stirred for another $30 \mathrm{~min}$. The clear solution was spread over on a glass slide via spin- or drop-casting coating methods to obtain fresh thin and thick films, respectively, of the mesophases. Spin coating (at $2000 \mathrm{rpm}$ ) ensures the immediate evaporation of ethanol and gelation, but in the drop-cast coated sample, the gelation takes 10-30 minutes, depending on the thickness of the drops. Finally the coated samples were calcined at various temperatures $\left(250,300,350,400,450\right.$, and $\left.500{ }^{\circ} \mathrm{C}\right)$ for $1 \mathrm{~h}$ to produce mesoporous nickel oxide films or monoliths. The schematic representation of the procedure is given in Fig. S12. $\dagger$

\section{Characterization}

X-ray diffraction (XRD) patterns were collected using a Rigaku Miniflex diffractometer, equipped with a $\mathrm{Cu} \mathrm{K} \alpha(\lambda=1.54056 \AA)$ $\mathrm{X}$-ray source, operating at $30 \mathrm{kV} / 15 \mathrm{~mA}$ and a Scintillator NaI (T1) detector with a Be window and a Pananalytical X'Pertpro Multipurpose X-ray diffractometer equipped with a $\mathrm{Cu} \mathrm{K} \alpha(\lambda=$ $1.5405 \AA$ ) X-ray source, operating at $45 \mathrm{kV} / 40 \mathrm{~mA}$ using drop cast coated and calcined samples for wide angle regions and spin coated fresh samples for small angle measurements. Polarized optical microscopy (POM) images of the gel phases were recorded using a ZEISS Axio Scope A1 polarizing optical microscope. $\mathrm{N}_{2}$ adsorption-desorption isotherms were collected using a Micromeritics Tristar 3000 automated gas adsorption analyzer in the range of 0.01 to $0.99 P / P_{\mathrm{o}}$. The samples were dehydrated under a vacuum of 35-40 mTorr at $200{ }^{\circ} \mathrm{C}$ for $2 \mathrm{~h}$ prior to measurements. Scanning electron microscopy (SEM) images were recorded using a FEI Quanta 200 F scanning electron microscope on aluminum sample holders. 
Transmission electron microscopy (TEM) images were recorded on a FEI Technai G2 F30 at an operating voltage of $200 \mathrm{kV}$. The samples (spin coated at $5000 \mathrm{rpm}$ and calcined at various temperatures for $1 \mathrm{~h}$ ) were scraped from the glass slide, ground in a mortar, and dispersed in $5 \mathrm{~mL}$ ethanol for $10 \mathrm{~min}$ using a sonicator. Then, a few drops of the above mixture were placed on a TEM grid and dried for 15 min under a powerful light source. The UV-vis absorption spectra were recorded using a Varian Carry 300 UV-vis double beam spectrophotometer with a $600 \mathrm{~nm} \min ^{-1}$ scan rate and $1 \mathrm{~nm}$ data interval over a wavelength range of 200 to $800 \mathrm{~nm}$ using thin films coated over quartz slides. XPS spectra were collected using a Thermo Scientific K-alpha X-ray photoelectron spectrometer operating with $\mathrm{Al} \mathrm{K} \alpha$ micro-focused monochromatic source $(1486.6 \mathrm{eV}$ and $400 \mu \mathrm{m}$ spot size) along with a flood gun for charge neutralization. The scraped powder samples from FTO electrodes (before and after 1000 cyclic voltammetry (CV) cycles in a potential range of $-0.4 \mathrm{~V}$ to $1.2 \mathrm{~V}$ with a scan rate of $200 \mathrm{mV}$ $\mathrm{s}^{-1}$ ) were put on a copper tape for XPS analysis. X-ray absorption near edge spectra (XANES) were collected on a SESAME EXAFS beamline (Allan, Jordan) by packing a calculated amount of the pressed sample and sandwiching on a sticky type. The XANES data were collected using samples calcined at 300, 400, and 600 ${ }^{\circ} \mathrm{C}$ and a sample calcined at $400{ }^{\circ} \mathrm{C}$ exposed to $100 \mathrm{CV}$ cycles between -1 and $2 \mathrm{~V}$ against a $\mathrm{Ag} / \mathrm{AgCl}(3.5 \mathrm{M} \mathrm{KCl})$ reference electrode with a scan speed of $100 \mathrm{mV} \mathrm{s}^{-1}$. Electrochemical studies were carried out in a $1.0 \mathrm{M} \mathrm{KOH}$ solution using $\mathrm{m}-\mathrm{NiO}$ coated FTO as the working electrode, a Pt wire as the counter electrode and a $\mathrm{Ag} / \mathrm{AgCl}$ electrode as the reference electrode. Unless otherwise stated, CVs were recorded with a scan rate of $50 \mathrm{mV} \mathrm{s}{ }^{-1}$ between 0.0 and $1.5 \mathrm{~V}$ (vs. Ag/AgCl). Spectroelectrochemical measurements were conducted in a standard quartz cuvette. A fiber optic Gamry Instruments SPECTRO-115E spectrometer fitted with a Gamry Instruments tungsten/deuterium source was used to collect the UV-vis spectra. The spectra were recorded in the wavelength range of $350 \mathrm{~nm}$ to $1050 \mathrm{~nm}$ with an integration time of $5 \mathrm{~ms}$ and 100 spectra were averaged for each data point shown in the figures. Using Gamry Framework 7.0.4 software and the accompanying "SpectroCyclic Voltammetry" script, it was possible to synchronize the electrochemical experiment with the acquisition of UV-vis spectra. For electrochemical experiments a Gamry Instruments 5000 potentiostat was used. The three-electrode setup consisted of the coated FTO electrodes as the working electrode, an Ag/ $\mathrm{AgCl}$ electrode as the reference electrode and a Pt wire as the counter electrode. Before each run, to normalize the composition of the sample surface, a reducing potential of $-0.5 \mathrm{~V}(v s$. $V_{\text {ref }}$ ) was applied for 5 minutes and subsequently the potential sweep was applied with a sweep rate of $20 \mathrm{mV} \mathrm{s}^{-1}$ for at least 3 cycles. The reported CVs for each case represents a steady state response (i.e. no appreciable change occurs between cycles). $\mathrm{pH}$ dependent electrochemical studies were carried out in buffered solution in a pH range of 7 to 13 . A pH 7 standard regularly used for calibration of $\mathrm{pH}$ meters was used as the $\mathrm{pH} 7$ buffer. A pH 8 buffer was prepared by mixing $100 \mathrm{~mL} 0.025 \mathrm{M} \mathrm{Na}_{2} \mathrm{~B}_{2} \mathrm{O}_{4} \cdot 10 \mathrm{H}_{2} \mathrm{O}$ with $41 \mathrm{~mL} 0.1 \mathrm{M} \mathrm{HCl}$ and subsequent dilution to $200 \mathrm{~mL}$ with deionized water. A pH 9 buffer was similarly prepared by mixing
$100 \mathrm{~mL} 0.025 \mathrm{M} \mathrm{Na}_{2} \mathrm{~B}_{2} \mathrm{O}_{4} \cdot 10 \mathrm{H}_{2} \mathrm{O}$ with $9.2 \mathrm{~mL} 0.1 \mathrm{M} \mathrm{HCl}$ and diluting to $200 \mathrm{~mL}$. The common pH 10 standard buffer usually contains EDTA which can interfere with electrochemical measurements; therefore, a pH 10 buffer was prepared by dissolving $4.77 \mathrm{~g} \mathrm{Na}_{2} \mathrm{~B}_{2} \mathrm{O}_{4} \cdot 10 \mathrm{H}_{2} \mathrm{O}$ in $183 \mathrm{~mL}$ of $0.1 \mathrm{M} \mathrm{NaOH}$ and diluting to $1 \mathrm{~L}$ with de-ionized water. A $\mathrm{pH} 11$ buffer was prepared by mixing $100 \mathrm{~mL} 0.05 \mathrm{M} \mathrm{Na}_{2} \mathrm{HPO}_{4}$ with $8.2 \mathrm{~mL} 0.1 \mathrm{M}$ $\mathrm{NaOH}$ and diluting to $200 \mathrm{~mL}$ total volume with de-ionized water. A pH 12 solution was prepared by mixing $50 \mathrm{~mL}$ of $0.2 \mathrm{M}$ $\mathrm{KCl}$ with $12 \mathrm{~mL} 0.2 \mathrm{M} \mathrm{NaOH}$ and diluting to $200 \mathrm{~mL}$. Finally, a pH 13 solution was prepared by mixing $50 \mathrm{~mL} 0.2 \mathrm{M} \mathrm{KCl}$ with $132 \mathrm{~mL} 0.2 \mathrm{M} \mathrm{NaOH}$ and again diluting to $200 \mathrm{~mL}$ total volume. The exact value of the $\mathrm{pH}$ for all the prepared buffers was measured using a $\mathrm{pH}$ probe that is 3 point calibrated using standard solutions and these measured values were reported. Using these solutions as the electrolyte, cyclic voltammograms were recorded at $20 \mathrm{mV} \mathrm{s}^{-1}$ with a Gamry Instruments Interface 5000 potentiostat in a three-electrode setup with the coated FTO samples as the working electrode, an $\mathrm{Ag} / \mathrm{AgCl}$ electrode as the reference electrode and a Pt wire as the counter electrode.

\section{Conclusions}

Nickel nitrate hexahydrate and surfactants (CTAB and $\mathrm{C}_{12} \mathrm{E}_{10}$ ) form a liquid crystalline mesophase over a broad range of salt concentrations (2-30 Ni(II)/ $\mathrm{C}_{12} \mathrm{E}_{10}$ mole ratio). The mesophases are stable at low salt concentration (2-6 mole ratio) but leaches salt as salt crystals at high salt concentrations. Leaching is a kinetic process and takes several days at low salt (6-12 mole ratio) concentrations and several minutes at very high salt (such as 30 mole ratio) concentrations. However, all compositions can be calcined immediately after gelation to produce mesoporous nickel oxide. High quality films can be obtained by using intermediate compositions (6-12 mole ratio), but relatively lower quality films (very fragile) can also be obtained by using higher $\mathrm{Ni}(\mathrm{II})$ /surfactant ratios. Mesoporous NiO films have a relatively high surface area, as high as $257 \mathrm{~m}^{2} \mathrm{~g}^{-1}$ (at $300{ }^{\circ} \mathrm{C}$ ) but it gradually decreases to $21 \mathrm{~m}^{2} \mathrm{~g}^{-1}$ at around $500{ }^{\circ} \mathrm{C}$. While the crystalline NiO pore-walls grow (from 3 to $27 \mathrm{~nm}$ ), the pores expand (from 3.6 to $16.9 \mathrm{~nm}$ ) upon annealing the films at elevated temperatures. The method introduced in this work allows one to control the surface area, pore size, crystalline pore wall size and thickness of the films which may be desired for various applications. The method can also be expanded to produce thin films of other transition metal and mixed metal oxides.

Thin m-NiO films display a good electrocatalytic performance for water oxidation and electrochromic behavior under basic conditions. Both water oxidation and electrochromic processes have the same origin in that in the first CV cycle and the consecutive cycles or during the water oxidation process, the top few layers of $\mathrm{NiO}$ are converted into $\mathrm{Ni}(\mathrm{OH})_{2}$ creating a surface skin/shell over the nanocrystalline NiO pore-walls (see Scheme 2). Upon further oxidation/reduction cycles during CV or water oxidation processes, switching the color of the electrode in the electrochromic process takes place between $\mathrm{Ni}(\mathrm{OH})_{2}$ and NiOOH species. During the use of the electrode, it is likely that the surface morphology changes by further 
conversion of the $\mathrm{NiO}$ core into the $\mathrm{Ni}(\mathrm{OH})_{2}$ shell; the $\mathrm{Ni}(\mathrm{OH})_{2}$ shell slowly grows over use and creates more active surface/ surface species.

A low electrode resistance that can be achieved by increasing the annealing temperatures is more important than electrode surface area at high current densities for the electrocatalysis of water oxidation. The likely active species for efficient electrocatalysis is the $\mathrm{Ni}^{4+}$ species formed over the electrode surface. However, electrochromic switching occurs between $\mathrm{Ni}^{3+}$ (dark) and $\mathrm{Ni}^{2+}$ (clear) species, where the surface area is more critical unless fast switching is required. Overall, the MASA process is an effective way of synthesizing mesoporous nickel oxide thin film electrodes for various electrochemical applications.

\section{Conflicts of interest}

There are no conflicts to declare.

\section{Acknowledgements}

The authors thank beamline scientists Dr Messaoud Harfouche (from SESAME, Allen Jordan), Mr Kerem Emre Ercan and Ms Ișıl Uzunok for their help with XANES and Mr Mustafa Güler for TEM measurements. We also thank TÜBİTAK (under the project number 118Z820) for the financial support of this work and the Turkish Atomic Energy Agency for the travel grant for the XANES measurements. Ö.D. is a member of the Science Academy, Istanbul, Turkey.

\section{Notes and references}

1 S. Vijayakumar, S. Nagamuthu and G. Muralidharan, ACS Appl. Mater. Interfaces, 2013, 5, 2188.

2 C. Yuan, X. Zhang, L. Su, B. Gao and L. Shen, J. Mater. Chem., 2009, 19, 5772 .

3 A. Nattestad, A. J. Mozer, M. K. R. Fischer, Y. B. Cheng, A. Mishra, P. Bauerle and U. Bach, Nat. Mater., 2010, 9, 31.

4 M. Gao, W. Sheng, Z. Zhuang, Q. Fang, S. Gu, J. Jiang and Y. Yan, J. Am. Chem. Soc., 2014, 136, 7077.

5 S. Y. Kim, H. M. Jeong, J. H. Kwon, W. Ock, W. H. Suh, G. D. Stucky and J. K. Kang, Energy Environ. Sci., 2015, 8, 188. 6 Y. Chen, Y. Wang, P. Sun, P. Yang, L. Du and W. Mai, J. Mater. Chem. A, 2015, 3, 20614.

7 M. Khairy and S. A. El-Safty, RSC Adv., 2013, 3, 23801.

8 A. S. Poyraz, C.-H. Kuo, S. Biswas, C. K. Kingondu and S. L. Suib, Nat. Commun., 2013, 4, 2952.

9 J. Lee, M. C. Orilall, S. C. Warren, M. Kamperman, F. J. Disalvo and U. Wiesner, Nat. Mater., 2008, 7, 222.

10 X. Li, C. Shen, P. Xue, B. Yan, H. Wang, P. Li, W. Xia and J. Fang, Nanoscale, 2015, 7, 4005.

11 D. Wang, C. Song, Z. Hu and X. Fu, J. Phys. Chem. B, 2005, 109, 1125.

12 S. R. Nalage, M. A. Chougule, S. Sen and V. P. Patil, Thin Solid Films, 2012, 520, 4835.

13 P. A. Nelson, J. M. Elliott, G. S. Attard and J. R. Owen, Chem. Mater., 2002, 14, 524.

14 J. Su and E. Wu, Microporous Mesoporous Mater., 2013, 168, 188.
15 M.-W. Xu, S.-J. Bao and H.-L. Li, J. Solid State Electrochem., 2007, 11, 372.

16 H. Liu, G. Wang, J. Liu, S. Qiao and H. Ahn, J. Mater. Chem., 2011, 21, 3046.

17 K. Xu, R. Zou, W. Li, Q. Liu, T. Wang, J. Yang, Z. Chen and J. Hu, New J. Chem., 2013, 37, 4031.

18 H. Qutaish, S. Tanaka, Y. V. Kaneti, J. Lin, Y. Bando, A. A. Alshehri, S.-I. Yusa, Y. Yamauchi, Md. S. A. Hossain and J. Kim, Microporous Mesoporous Mater., 2018, 271, 16.

19 A. Eftekhari, Microporous Mesoporous Mater., 2017, 243, 355.

20 X. Zheng, H. Wang, C. Wang, Z. Deng, L. Chen, Y. Li, T. Hasan and B.-L. Su, Nano Energy, 2016, 22, 269.

21 L. Guo, H. Arafune and N. Teramae, Langmuir, 2013, 29, 4404. 22 Y. Ren, Z. Ma and P. G. Bruce, Chem. Soc. Rev., 2012, 41, 4909. 23 P. Yang, D. Zhao, D. I. Margolese, B. F. Chmelka and G. D. Stucky, Nature, 1998, 396, 152.

24 P. Yang, D. Zhao, D. I. Margolese, B. F. Chmelka and G. D. Stucky, Chem. Mater., 1999, 11, 2813.

25 S. Y. Choi, M. Mamak, N. Coombs, N. Chopra and G. A. Ozin, Adv. Funct. Mater., 2004, 14, 335.

26 A. Rumplecker, F. Kleitz, E.-L. Salabas and F. Schüth, Chem. Mater., 2007, 19, 485.

27 X. Deng, K. Chen and H. Tüysüz, Chem. Mater., 2016, 29, 40. 28 W. Luc and F. Jiao, Acc. Chem. Res., 2016, 49, 1351.

29 C. Karakaya, Y. Türker, C. Albayrak and Ö. Dag, Chem. Mater., 2011, 23, 3062.

30 C. Karakaya, Y. Türker and Ö. Dag, Adv. Funct. Mater., 2013, 23, 4002.

31 C. Avcı, A. Aydın, Z. Tuna, Z. Yavuz, Y. Yamauchi, N. Suzuki and Ö. Dag, Chem. Mater., 2014, 26, 6050.

32 G. Saat, F. M. Balci, E. P. Alsaç, F. Karadas and Ö. Dag, Small, 2018, 14, 1870003.

33 F. M. Balci, I. Karakaya, E. P. Alsaç, M. Y. Yaman, G. Saat, F. Karadas, B. Ülgüt and Ö. Dag, J. Mater. Chem. A, 2018, 6, 13925.

34 C. C. Lin and C. C. L. McCrory, ACS Catal., 2017, 7, 443.

35 L. Trotochaud, J. K. Rnney, K. N. Williams and S. W. Boettcher, J. Am. Chem. Soc., 2012, 124, 17253.

36 X. Deng, S. Öztürk, C. Weidenthaler and H. Tüysüz, ACS Appl. Mater. Interfaces, 2017, 9, 21225.

37 D. Wang, F. Watanabe and W. Zhao, ECS J. Solid State Sci. Technol., 2017, 6, M3049.

38 D. S. Hall, D. J. Lockwood, C. Bock and B. R. MacDougall, Proc.: Math., Phys. Eng. Sci., 2015, 471, 20140792.

39 Y. Dou, L. Zhang, J. Xu, C.-T. He, X. Xu, Z. Sun, T. Liao, B. Nagy, P. Liu and S. X. Dou, ACS Nano, 2018, 12, 1878.

40 B. Kim, A. Oh, M. K. Kabiraz, Y. Hong, J. Joo, H. Baik, S.-I. Choi and K. Lee, ACS Appl. Mater. Interfaces, 2018, 10, 10115.

41 G. Boschloo and A. Hagfeldt, J. Phys. Chem. B, 2001, 105, 3039.

42 A. Renaud, B. Chavillon, L. Cario, L. L. Pleux, N. Szuwarski, Y. Pellegrin, E. Blart, E. Gautron, F. Odobel and S. Jobic, J. Phys. Chem. C, 2013, 117, 22478.

43 M. A. Peck and M. A. Langell, Chem. Mater., 2012, 24, 4483. 